DOI: http://dx.doi.org/10.24093/awejtls/vol1no1.7

\title{
Sadallah Wannous: Towards an indigenous Arabic Epic theater: An applied study of An Evening Entertainment and The Adventure of Slave Jaber's Head
}

\author{
Samar Zahrawi \\ Department of World Languages and Cultures \\ College of Humanities and Social Sciences \\ Sam Houston State University, Huntsville, TX, USA
}

\begin{abstract}
The leading Syrian dramatist, Sadallah Wannous (1941-1997), aimed at creating an original Arabictheater. He theorized about the theater of politicization, which has a progressive political content and is intended to instigate the masses to recognize their plight and take part in changing it. To do this, he used anti-realistic techniques that he borrowed from Brecht's epic theater and established a warm improvised dialogue between the stage and the auditorium. In order to create instantaneous connection with the local audience, the dramatist embraced Arabic history and literary traditions and maneuvered them in order to address contemporary Arabic issues.Eventually, the middle period of Wannous's production (1968-1978) is a breakthrough in Arabic theater in which Brechtian epic theater is adapted to Arabic themes and plotlines and is made organically connected to the longings and needs of contemporary Arabaudience. The aim of this study is toprovide a critique of Wannous's indebtedness to Brecht and to local Arabic tradition, on the one hand, and his own ingenuity in creating an indigenous Arabic theater, on the other. To do so, this article locates Wannous's dramatic contribution in the context of Arabic traditions and Brechtian theater and provides an applied study of two plays; An Evening Entertainment for the Fifth of June (1968) and The Adventure of the Slave Jaber's Head (1970). The study delves into Wannous's use of local theatrical devices such as the storyteller (Hakawati), and Karakoz and traditional and historical plot lines within an overall epic theatrical form. As a conclusion, this article demonstrates that Wannous's dramatic production in the middle period creatively fuses both Brechtian and traditional Arabic theatrical practices and comes out as a distinctly new Arabic theater.
\end{abstract}

Key words: Alienation, epic theater, indigenous Arabic epic theater,theater of politicization, Syrian drama, Wannous

Cite as: Zahrawi, S. (2017). Sadallah Wannous: Towards an indigenous Arabic Epic theater: An applied study of An Evening Entertainment and The Adventure of Slave Jaber's Head. Arab World English Journal for Translation \& Literary Studies, 1(1).

DOI: http://dx.doi.org/10.24093/awejtls/vol1no1.7 